\title{
THE ABRUPT FALL OF THE LABOR MARKET: THE CASE OF THE EUROPEAN LABOR MARKET AND THE IMPACT GENERATED BY COVID-19
}

\author{
Cristina PRUND ${ }^{a *}$ \\ ${ }^{a}$ Lucian Blaga University of Sibiu, Romania
}

\begin{abstract}
The whole world is facing the challenge generated by COVID-19 and a lot of countries are affected from a lot of perspectives: health, economy, politics, etc. The paper is going to focus on the economical perspective and more precisely on the changes that occurred in the labor market. Since the beginning, the new and dangerous virus left his mark on a lot of businesses from different industries which finally recorded strong decreases being forced either to restrict the activity or to suspend it. The COVID-19 crisis is changing completely the labor market and it forces employees and employers to adapt to this new reality. The present research is trying to find out how COVID19 is affecting different industries from all over the Europe and how employers and employees are trying to survive during and after the present crisis. The objectives of the paper are (1) To analyze the recent literature on this subject; (2) To investigate the changes generated by Covid19 on the labor market (3) To identify which are the most affected sectors/industries. According to the methodology the paper is analyzing recent studies and statistics and by interpreting them it highlights a series of essential aspects and opportunities for future studies which will represent the intended contribution. The results will try to conclude that the effects of the crisis are different from a country to another and that this crisis is just another challenge that the labor market has to overcome emphasizing two important aspects: health protection and economic support.
\end{abstract}

KEYWORDS: adaptation, challenge, Covid-19, Labor market.

\section{INTRODUCTION}

The current crisis generated by COVID is no longer considered a health crisis, it became an economic crisis. Based on the Covid situation report from 10 of august 2020, The World Health Organization reported a number of 3.582.911 cases in Europe with a number of 17.627 new cases in the last 24 hours (WHO, 2020).

All over Europe have been implemented a series of control actions which are used to stop and to control the spread of the virus. For example, countries developed policies that include mandatory mask wearing, local movement restrictions and physical distancing measures.

Employment contracts have been suspended in companies that are unable to comply with social distancing directives, or which have experienced an immediate fall in demand for their products and services (Baert et al., 2020).

As reported by the International Labor Organization (2020), the global labor market is facing the "worst crisis since World War II because of COVID-19".

\footnotetext{
* Corresponding author. E-mail address: cristina.prund@ulbsibiu.ro
} 
Several recent studies have indicated that the European labor market will be significantly impacted by Coronavirus pandemic. In addition, taking into consideration the lockdown, a huge number of employees may have lost their jobs or the opportunity to start a new job.

There are a few examples of companies that were or will be forced to reduce the number of jobs: According to the Reuters (2020) and The Independent (a British online newspaper), the Ryanair Company is planning to cut off around 3.000 jobs, while Renault and Airbus around 15.000 jobs. Some of these companies already took this extreme measure and started to cut off the number of jobs, while others are taking into consideration to do it in the future based on the COVID-19's effects evolution. We suppose this is a measure they are forced to take in order to absorb the shock generated by the global pandemic.

The SARS-COV-2 situation represents a severe economic stress test for all the European countries and also for the European unity (Bénassy-Quéré et al., 2020).

\section{LITERATURE BACKGROUND}

\subsection{Literature review}

A series of actual studies have shown that the crisis generated by COVID-19 is impacting the world from several perspectives: economy, goods, services, health and last but not least the labor market. In the context of COVID-19, The Institute for Employment studies (an independent, apolitical, international center of research and consultancy in public employment policy and HR management) found out that the present crisis has led to an economic shock that is unprecedented in modern history in its size and speed.

This represents a complex problem because every industry is facing serious challenges and some of the most affected ones are: aviation, tourism and hospitality industries (ILO, 2020).

Dias et al. (2020) in their paper assume that not all sectors are being equally affected, but some will certainly see very persistent, or even permanent, effects that result from changes in habits, preferences and technologies while Hensvik et al. (2020) suggest that the shock does not operate through uniform reduction across industries, and that different occupations within the same industry are affected differently.

Some authors have also suggested that it is important to keep employees committed to their employers because in this way, when the lockdown restrictions will end, they can easily come back to their jobs.

There are some workers - particularly those who had relatively little experience in their current firm, such as young workers - who would be better off finding new work than waiting months for their old employment to come back. There is a key balance to be struck, between reallocating some workers to jobs or sectors where their future will be brighter and the need to have firms that make it through the crisis ready to quickly resume 'business as usual', without requiring an inefficient round of hiring of workers who will have no previous experience with that firm (Dias et al., 2020). From another perspective, this kind of recessions could lead to a phenomenon defined as "discouraged workers", in which a part of the unemployed workers stop searching a job, and that is the reason why Coibion et al. (2020) tried to find out why do so many people choose not to search a job. Based on their research where they took into consideration a global survey realized by the Nielsen (a leading global information \& measurement company) they presented a few answers to the previous question: some of them were retired, spending time with their children, they were studying, or did not need to find a job. $1.6 \%$ of those out of the labor market were claiming that they didn't find a place where to work because they were not searching.

In addition to the earlier statement the stay-at-home directives make it nearly impossible for nonessential workers who cannot work from home to keep up their work. Researchers estimate that only about a third of workers have jobs where work from home is possible (Kahn et al., 2020). 
Moreover, even if after the crisis all workers are able to find a firm that is as well matched to them as the firm they worked for pre-crisis, the one-off cost of the massive round of hiring that would need to take place as the public health crisis passes would itself be significant (Dias et al., 2020). The policy choice facing governments is often portrayed as a simple trade- between saving lives and saving the economy (Andersen et al., 2020).

By this logic, more severe restrictions help contain the virus and reduce the ultimate death toll but cause more economic pain as more households cut spending, more businesses go bankrupt and more workers lose their jobs (Gourinchas, 2020).

From the perspective of the macroeconomy, business failures mean the destruction of intangible capital and even the loss of some physical capital, particularly in light of costly capital reallocation. From the perspective of communities and neighborhoods, business failure means dramatic, sometimes irreversible changes to the local physical economic landscape (Cajner et al., 2020). According to OECD (2020) latest Economic Outlook the Covid-19 pandemic has triggered the most severe recession in nearly a century and is causing enormous damage to people's health, jobs and well-being.

\subsection{Conceptual framework}

Many studies have shown that COVID-19 has affected and will affect in the future the labor market. In this regard, we analyzed a part of those studies in order to find out which are the most relevant keywords used in different research. The findings in Figure 1 show some relevant keywords based on data from two databases: Scopus and Web of Science.

In order to be able to identify critical factors, we used VosViewer software tool. VOSViewer is used for visualizing and analyzing trends in the form of bibliometric maps (Durana et al., 2020). In other words, with this software we are able to reveal which is the latest trend regarding COVID-19 and the labor market and to generate visual representations of COVID-19 and the effects generated on the labor market (unemployment, social distancing, lockdown). The articles for this research were chosen from international journals: Journal Of Public Economics, Economic And Political Weekly, Environmental And Resource Economics, Studies In Business And Economics; Journal Of Health Economics, and from different areas: Business, Management and Accounting, Economics, Econometrics and Finance.

We identified 3 clusters which are presented by the findings in Figure 1: Blue, green and red. The first one is focused on the following words: government, response, lockdown, effect, risk, measure, covid, health, virus, country, outbreak, spread, case, social distancing. We can suppose that the authors took into considerations which was the impact created by COVID-19 in different countries and what measures have been taken by the government in order to stop the spread of the virus.

The green cluster is presenting a different perspective based on the identified factors: unemployment, employment, sector, crisis, pandemic, impact, economy, world. In this case, we can highlight another important fact: The pandemic had a severe impact over the world, affecting different countries and sectors by generating a crisis and a high unemployment rate.

The red cluster is focusing on the labor market and identifies the following crucial factors: employee, worker, work, change, job, home, occupation, industry, difference, labor market, march.

Because of the pandemic a lot of industries were affected and in this regard they had 3 posibilities: (1) to suspend their activity for a period of time; (2) to close their activity; (3) to give their employees the possibility to work from home.

By using the VosViewer software we can highlight three important directions which are essential to be taken into consideration for future research: (1) Which are the effects generated by COVID in different countries and how the government is trying to solve the existing problem?

(2) How can the labor market be prepared to face the crisis in order to maintain a normal rate of unemployment? (3) Which are the best possibilities for the affected companies to be able to save their employees but also their activity? 


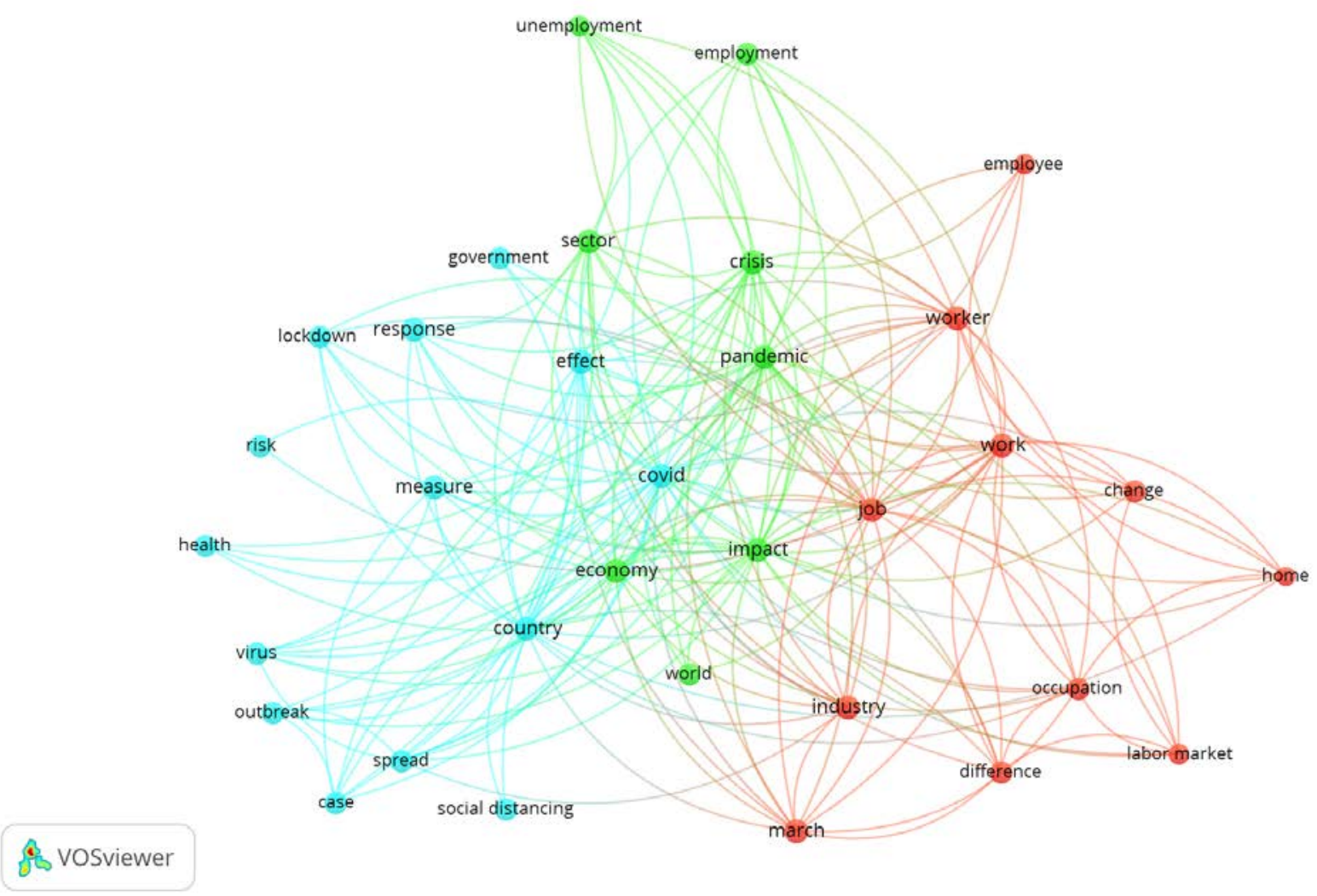

Figure 1. VosViewer: Keywords from Scopus and Web of Science database

Source: Composed by the author on the basis of the information generated by Vosviewer soft

\section{THE ABRUPT FALL OF THE LABOR MARKET}

In December 2019, the COVID-19 outbreak was registered in Wuhan China. The World Health Organization declared it a "Public Health Emergency of International Concern" on January 30, 2020 and escalated it to a pandemic on March 11, 2020. The disease has been recorded in over 200 countries and territories with several millions of confirmed cases and a case mortality rate of around seven percent (Askitas et al., 2020). It was just a matter of time until the pandemic had significant effects all over the world. We are all influenced about the way in which the actual crisis generated by COVID-19 has affected the national economies.

There is evidence based on research that shows how almost all the sectors and industries are affected at global level and how they are trying to adapt to this new reality. The labor market was another important sector that has been affected in Europe by the crisis's drastic effects suffering a lot of changes based on the new challenges.

There were a lot of months that employees spent in their houses without being able to go to their office, period in which the business environment made huge efforts in order to maintain employee's jobs.

Because of the drastic decreases the companies feel a huge pressure based on the fact that they are forced to take strong measures to be able to maintain the activity. The first experience when the companies had to adapt to this kind of challenge happened in 2008-2010 when the economic crisis hit the world. Compared to the crisis from that moment, now the companies were forced to change and adapt their policies faster because of the different regulations given by each country. 


\subsection{Analysis of the industries and sectors}

Companies from tourism, transport, events sectors are the ones who had been the most affected during and after the crisis because of all the restrictions given worldwide.

From another point of view, if we take a look at retailing and food delivery, we can notice that they were not affected as much as other sectors. We believe that this is possible because some of them managed to continue with their activity in the online environment while others continued their activity in normal conditions, especially the ones that are selling essential products, like supermarkets.

Table 1. Analyze of the impact index by industry and dimension on a scale from 1 (minor) to (5) severe

\begin{tabular}{|l|c|c|c|c|c|}
\hline Impact index & $\begin{array}{c}\mathbf{1} \\
\text { (minor) }\end{array}$ & $\begin{array}{c}\mathbf{2} \\
\text { (moderate) }\end{array}$ & $\begin{array}{c}3 \\
\text { (significant) }\end{array}$ & $\begin{array}{c}\mathbf{4} \\
\text { (major) }\end{array}$ & $\begin{array}{c}5 \\
\text { (severe) }\end{array}$ \\
\hline Sector/Dimension & Personnel & Operations & $\begin{array}{c}\text { Supply } \\
\text { Chain }\end{array}$ & Revenue & $\begin{array}{c}\text { Overall } \\
\text { Assessment }\end{array}$ \\
\hline Manufacturing & 5 & 5 & 5 & 5 & 5 \\
\hline $\begin{array}{l}\text { Travel \& } \\
\text { Transportation }\end{array}$ & 5 & 5 & 5 & 5 & 5 \\
\hline Retail & 5 & 4 & 5 & 4 & 5 \\
\hline $\begin{array}{l}\text { Energy \& } \\
\text { Resources }\end{array}$ & 4 & 4 & 5 & 4 & 4 \\
\hline $\begin{array}{l}\text { High Tech \& } \\
\text { Telecommunicatio } \\
\text { n }\end{array}$ & 3 & 4 & 5 & 5 & 4 \\
\hline $\begin{array}{l}\text { Healthcare \& Life } \\
\text { Sciences }\end{array}$ & 2 & 5 & 4 & 4 & 4 \\
\hline Non-profits & 5 & 4 & 1 & 5 & 4 \\
\hline $\begin{array}{l}\text { Media \& } \\
\text { Entertainment }\end{array}$ & 3 & 5 & 2 & 3 & 4 \\
\hline $\begin{array}{l}\text { Universities \& } \\
\text { Colleges }\end{array}$ & 5 & 2 & 1 & 5 & 3 \\
\hline $\begin{array}{l}\text { Banking, Financial } \\
\text { Sector \& Insurance }\end{array}$ & 3 & 3 & 1 & 3 & 3 \\
\hline \begin{tabular}{l} 
Public Sector \\
\hline
\end{tabular} & 4 & 5 & 5 & 4 & 4 \\
\hline
\end{tabular}

Source: adapted from Statista Research, Arne Holst(2020)

Statista (a German online portal for statistics) conducted a research where they tried to find out the impact index by industry and dimension on a scale from 1 (minor) to (5) severe. The result of the research are presented below.

As we can notice in the findings in Table 1, travel, transportation and manufacturing are some of the most impacted sectors. The research has shown that these industries are impacted in a severe way in all 5 dimensions that were taken into consideration: Personnel, Operations, Supply Chain, Revenue, Overall Assessment. From another point of view, we can say that a huge number of industries were affected regarding the personnel: For example, there are 5 industries (Manufacturing, Travel \& Transportation, Retail-most probably the ones that were not able to 
continue their activity in online environment, Non-profits, University and colleges which scored the impact index 5, while the other 2 (Energy and Resources and Public Sector) scored 4.

Another dimension of interest is the revenue. The findings in the figure show that there are 6 sectors that are severely impacted, while the other ones are scored between 3- 4 reflecting also a significant and major impact. We consider this is an essential dimension to be taken into consideration because if companies will have problems with the revenue, it will decrease the possibility to pay employee salaries or to continue with the activity and to sustain the jobs.

In their study, Fana et al. (2020) considering information from official reports and additional information regarding the possibility to work from home identified five categories of sectors in Europe.

- Essential and fully active: food production, utilities, health;

- Active but via telework: education, public administration, finance, insurance and telecommunications;

- Mostly essential and partly active, not teleworkable: retail and manufacturing of chemicals and paper;

- Mostly non-essential and partly active, not teleworkable: manufacturing not previously mentioned, machine and computer repair activities and construction;

- Closed: hotels, restaurants and accommodation, estate and travel agencies, plus leisure and recreation services.

Table 2 will analyze a few indicators that are affected by Covid-19 in each of the categories described earlier: (1) Percentage of women; (2) Percentage of aged 15-29; (3) Percentage of aged 50+; (4) Percentage of self-employed; (5) Percentage of temporary employment; (6) Percentage of low-skilled workers; (7) Percentage of high-skilled workers.

Table 2. Percentage of indicators that are affected by Covid-19 in each of the categories: Essential; Teleworkable; Partly active; Mostly non essential; Closed

\begin{tabular}{|l|c|c|c|c|c|}
\hline \multicolumn{1}{|c|}{$\begin{array}{c}\text { EUROPEAN UNION } \\
\text { EU27 }\end{array}$} & Essential & Teleworkable & $\begin{array}{c}\text { Partly } \\
\text { active }\end{array}$ & $\begin{array}{c}\text { Mostly } \\
\text { non } \\
\text { essential }\end{array}$ & Closed \\
\hline $\begin{array}{l}\text { Women in each of the } \\
\text { categories }\end{array}$ & $51.05 \%$ & $52.90 \%$ & $48.45 \%$ & $24.44 \%$ & $56.29 \%$ \\
\hline $\begin{array}{l}\text { Aged 15-29 in each of the } \\
\text { categories }\end{array}$ & $16.02 \%$ & $14.93 \%$ & $21.61 \%$ & $17.30 \%$ & $28.34 \%$ \\
\hline $\begin{array}{l}\text { Aged 50+ in each of the } \\
\text { categories }\end{array}$ & $36.27 \%$ & $33.48 \%$ & $29.99 \%$ & $32.00 \%$ & $26.48 \%$ \\
\hline $\begin{array}{l}\text { Self-employed in each of } \\
\text { the categories }\end{array}$ & $15.19 \%$ & $11.07 \%$ & $14.51 \%$ & $13.64 \%$ & $21.66 \%$ \\
\hline $\begin{array}{l}\text { Temporary employment in } \\
\text { each of the categories }\end{array}$ & $14.07 \%$ & $12.09 \%$ & $14.02 \%$ & $13.29 \%$ & $21.58 \%$ \\
\hline $\begin{array}{l}\text { Low-skilled workers in each } \\
\text { of the categories }\end{array}$ & $19.12 \%$ & $6.42 \%$ & $21.51 \%$ & $22.40 \%$ & $22.46 \%$ \\
\hline $\begin{array}{l}\text { High-skilled workers in } \\
\text { each of the categories }\end{array}$ & $31.71 \%$ & $60.56 \%$ & $24.21 \%$ & $21.73 \%$ & $26.17 \%$ \\
\hline
\end{tabular}

Source: adapted from (Fana et al., 2020) 
The results from the table highlight several important aspects:

- The percentage of women is more pronounced in the closed and teleworkable sectors and that is the reason why we can say that women are more affected by Covid than men.

- There are less women working in the mostly nonessential sectors- like manufacturing and construction which can be considered an male sector.

- Most of the people working in the teleworkable sectors are the ones who are over 50 years old and we consider this could be a good fact, because it gives them the possibility not to expose so much and to protect themselves.

- $36.27 \%$ of employees aged 50+ are working in essential sectors compared to $16.05 \%$ younger employees aged 15-29. We consider this might be a problem because studies have shown that older people are more affected by COVID and for them the virus is more dangerous. In these conditions, if a part of the older employees will get infected with the virus it will create a difficult situation for the companies where they work especially because they work in essential sectors.

- 28. 64\% of employees aged between 15-29 and 26. $48 \%$ aged 50+ are working in closed sectors. This shows the fact that more than $50 \%$ of employees are affected by Covid effects because the company where they worked was forced to suspend or to stop the activity.

- $21.66 \%$ of employees who have their own business are working in closed sectors so they are facing difficult challenges in this period trying to protect their business.

- $21.58 \%$ of employees who are hired for temporary employment are working in closed sectors.

- A good fact is that $31.71 \%$ of high-skilled workers are working in essential sectors, compared to $19.12 \%$ of low-skilled workers working in the same sectors.

- Only 6. $42 \%$ of low skilled workers are working in teleworkable sectors compared to the ones that have high skills $31.71 \%$.

- The closed sectors are much more likely to have young employees (15 to 29 years) compared to the other ones.

\section{RESEARCH METHODOLOGY}

The research methodology is based on previous experiments and research and in this regard the paper is considering several official reports, actual articles, studies and books in the field.

We analyzed qualitative and quantitative secondary data from official sources like the World Health Organization, The International Labor Organization, The European Commission and we also explored the opinion of specialists in the field.

The data was divided into 2 perspectives:

(1) The paper took into consideration 5 dimensions: a) Personnel; b) Operations; c) Supply Chain; d) Revenue; e) Overall Assessment related to different working sectors: (a) Manufacturing; (b) Travel \& Transportation; (c) Retail; (d) Energy \& Resources; (e) High Tech \& Telecommunication; (f) Healthcare \& Life Sciences; (g) Non-profits; (h) Media \& Entertainment; (i) Universities \& Colleges; (j) Banking, Financial Sector \& Insurance; (k) Public Sector.

In this regard, the affected dimension was analyzed based on a 1(minor)-5(severe) impact scale and our data show that the most affected sectors are: Manufacturing and Travel \& Transportation.

(2) On the other hand, the data from the study is also centralizing, comparing and interpreting the results of a study conducted by The European Commission (2020), based on the indicators that were affected by COVID-19, where they considered the 27 countries which are part of the European Union. For this purpose, the paper analyzed the data collected from the European Countries. The analyzed data included a few indicators that are affected by Covid-19: 
Percentage of women; Percentage of aged 15-29; Percentage of aged 50+; Percentage of selfemployed; Percentage of temporary employment; Percentage of low-skilled workers; Percentage of high-skilled workers in relation to the following categories/sectors: Essential; Teleworkable; Partly active; Mostly non-essential; Closed.

\section{CONCLUSION}

The COVID-19 crisis is changing completely the labor market: If before the crisis we were talking about a market of the candidates, now everything has changed and we are talking about a market of the employers. We all wonder how life after COVID will look but for sure we can say that the companies will try to be more cautious and most probably will need to prepare a backup plan for similar situations that could occur in the future. From another perspective, companies will start to look for other abilities when they are choosing a candidate. For example, they will focus on candidates who are open and able to use and learn new technologies and especially on candidates who are able to quickly adapt to new changes and challenges.

We can highlight the fact that some countries were able to manage the COVID-19 effects in a more competently way than others. It is true that, the way in which different countries managed the crisis generated by SARS-COV-2 will have a lot of implications in the future.

According to International Labor Organization (2020) the pandemic generated a crisis which is unique from a lot of perspectives. There are a lot of lessons we and the labor market have to learn from other economic crises like the global financial crisis as well as epidemics: avian and swine flu, SARS, Ebola, which emphasizes the important role of employment, social protection and social dialogue in mitigation and recovery policies The present crisis is meant to teach us an essential lesson: It is very hard to be prepared for this kind of situation, but somehow the good fact is that we will develop the ability to adapt quickly to situations like this.

In the end, we can say that unfortunately we can not avoid the long-term damage caused by COVID on the labor market, but we do have to see the possibility to maximize the opportunity of a strong recovery and to minimize the negative effects.

\section{REFERENCES}

Andersen, K. G., Rambaut, A., Lipkin, W. I., Holmes, E. C. \& Garry, R. F. (2020). The proximal origin of SARS-COV-2. Nature Medicine, 26, 450-452.

Askitas, N., Tatsiramos, K. \& Verheyden, B. (2020). Lockdown strategies, mobility patterns and covid-19. Covid Economics - Vetted and Real-Time Papers, 23, 293-302.

Baert, S., Lippens, L., Moens, E., Sterkens, P. \& Weytjens, J. (2020). How do we think the COVID19 crisis will affect our careers (if any remain)? The IZA - Institute of Labor Economics, 13164, 2-29.

Bénassy-Quéré, A., Marimon, R., Pisani-Ferry, J., Reichlin, L., Schoenmaker, D. \& Di Mauro, B., W. (2020). COVID-19: Europe needs a catastrophe relief plan. VOX EU CEPR. Retrieved August 20, 2020, from https://voxeu.org/article/covid-19-europe-needs-catastrophe-relief-plan.

Cajner, T., Crane, L. D., Decker, R. A., Grigsby, J., Hamins-Puertolas, A., Hurst, E., et al. (2020). The U.S. Labor Market During the Beginning of the Pandemic Recession. Chicago: Becker Friedman Institute.

Coibion, O., Gorodnichenko, Y. \& Weber, M. (2020). Labor markets during the covid-19 crisis: A preliminary view. VOX EU CEPR. Retrieved August 20, 2020, from https://voxeu.org/article/labour-markets-during-covid-19-crisis-preliminary-view.

Dias, M. C., Joyce, R., Postel-Vinay, F. \& Xu, X. (2020). The Challenges for Labor Market Policy during the COVID-19 Pandemic. Fiscal Studies, 41(2), 371-382. 
Durana, P., Valaskova, K., Vagner, L., Zadnanova, S., Podhorska, I. \& Siekelova, A. (2020). Disclosure of strategic managers' factotum: Behavioral incentives of innovative business. International Journal of Financial Studies, 8(1), 17.

European Commission. (2020). The impact of COVID confinement measures on EU labor market. Bruxelles.

Fana, M., Tolan, S., Torrejón, S., Urzi Brancati, C. \& Fernández-Macías, E. (2020). The COVID confinement measures and EU labor markets. Luxembourg: Publications Office of the European Union, 30190, 1-32. doi:10.2760/079230.

Gourinchas, P.O. (2020). Flattening the pandemic and recession curves. VOX EU CEPR. Retrieved August 20, 2020, from https://voxeu.org/article/flattening-pandemic-and-recession-curves.

Hensvik, L., Barbanchon, T. L. \& Roland, R. (2020). Job Search during the COVID-19 Crisis.

IZA Discussion Papers, 13237, 1-17.

International Labor Organization. (2020). COVID-19 impact on the collection of labor market statistics. Geneva.

Reuters (2020). Potential Ryanair job cuts remain at 3,000. Reuters. Retrieved August 19, 2020, from https://www.reuters.com/article/us-ryanair-jobs/potential-ryanair-job-cuts-remain-at3000-spokeswoman-idUSKBN2424OR.

OECD. (2020). COVID-19 is causing activity to collapse and unemployment to soar. Paris.

WHO. (2020). Coronavirus disease (COVID-19) Situation Report - 203. Geneva. 